\title{
Liquefaction-induced settlement, site effects and damage in the vicinity of Yalova City during the 1999 Izmit earthquake, Turkey
}

\author{
Ferhat Ozcep ${ }^{1, *}$, Savaş Karabulut ${ }^{1}$, Oguz Özel ${ }^{1}$, \\ Tazegul OzceP ${ }^{2}$, Nazire İme $^{3}$ and Halil Zarif ${ }^{1}$ \\ ${ }^{1}$ Department of Geophysical Engineering, Istanbul University, Istanbul, 34320, Turkey. \\ ${ }^{2}$ Sirinevler Primary School, Sirinevler Ministry of National Education, Istanbul, Turkey. \\ ${ }^{3}$ Emek Geophysical and Geotechnical Company, Büyükçekmece, Istanbul, Turkey. \\ ${ }^{*}$ Corresponding author. e-mail: ferozcep@istanbul.edu.tr
}

\begin{abstract}
Yalova City (Turkey) is in a tectonically active location that is particularly affected by the northern branch of the North Anatolian Fault Zone. Magnitudes 7.4 and 7.2 earthquakes in 1999 caused great destruction in Yalova. The heavy damage to buildings and other civil engineering structures was mainly due to liquefaction-induced settlement and site effects such as resonance and amplification. In the first phase of this study, the soil liquefaction potential index $(P L)$ and the induced soil settlement were estimated. In the second phase, the effects on sites in Yalova soil were investigated using microtremor and earthquake data. The fundamental periods and amplification in soft soil were compared with microtremor data and strong ground motion records obtained by a local array of eight accelerograph stations deployed in Yalova. Thirty-seven 'single site' ambient noise measurements were taken in a dense grid of points covering the centre of the city. A comparison between fundamental periods obtained from strong ground motion records and from microtremor measurements showed similarities, in the $0.1-5 \mathrm{~Hz}$ range. Finally, soil liquefaction and amplification (or resonance) were divided into regions according to the extent of damage and the geotechnical/geophysical results.
\end{abstract}

\section{Introduction}

Soil/site conditions, as has been reported in many studies (e.g., Borcherdt and Gibbs 1976; Iglesias 1988; Lekkas 1996; Seed et al. 2001; Özel et al. 2002) play an effective role as one of the triggers of earthquake damage. The determination of site conditions requires, identification of the soil stratification and properties of soil layers based on detailed geotechnical and geophysical tests.

Yilmaz and Yavuzer (2005) carried out liquefaction-potential studies and susceptibility mapping in Yalova for a single ground motion level ( $M=7.4$ and related acceleration). Ozcep and Zarif (2009) investigated variations in soil liquefaction safety factors for several hypothetical earthquakes in Yalova, determining the safety factors for different ground motion levels (magnitudes 6.5, 7.0 and 7.5) and accelerations (0.2-0.50 g).

Several works have investigated site effects, both liquefaction-induced settlement and earthquake damage. Gueguen et al. (1998) reported on the site effects and damage distribution in Pujili (Ecuador) after the earthquake there on $28 \mathrm{March}$

Keywords. Earthquakes; structural damage; $V_{S} 30$; soil liquefaction; soil effect. 
1996. Lermo and Chavez-Garcia (1994) investigated site effects in Mexico City using dominantperiod and relative-amplification data from strong motion and microtremor records. Chou et al. (2001) studied the risk of liquefaction-related damage at a tunnel site in the Taipei Rapid Transit System, Taipei County. Juang et al. (2005) estimated the severity of liquefaction-induced damage near foundations.

In recent years, geophysicists and geotechnical/ earthquake engineers in many countries have been involved with the investigation of more earthquake damage problems related to soils than ever before. These problems are vitally important both for the people and the economic development of the affected countries. For this important situation to be understood, a combined effort will be needed to resolve soil-earthquake-structure interaction problems.

The present investigation set out to determine what role the soil properties play as one of the main factors causing earthquake damage in Yalova, and to compare the influence of two soil problems amplification and liquefaction - on earthquake damage. This study presents and discusses the causes of the earthquake damage in the Yalova region related to soil liquefaction (as indicated by the PL and settlement quantities) and site effects (microtremor motions, earthquake motions, and $V_{S} 30$ ).

This study compared a known empirical method with field geophysical/geotechnical data for assessing ground damage triggered by liquefaction and/or soil amplification at or near buildings in the vicinity of Yalova City during the 1999 Izmit earthquake in Turkey, including damage observations from the earthquake.

\section{Geology and local soil conditions in the region}

The geology and more than 200 drilling sites are shown in figure 1 . The site is characterized by very large Quaternary alluvial deposits, and the Tertiary Yalakdere and Kilic formations. The Quaternary deposits consist of stratified materials having varied grain sizes, and are derived from the various geological units in the vicinity (Yilmaz and Yavuzer 2005).

The main drainage system is dominated by the Samanli, Safran, Balaban and Kazimiye rivers. Borehole records throughout the study area show that the groundwater table is generally very shallow. It is closely associated with the amount of precipitation and may rise significantly following high monthly precipitation to depths between 0.5 and $3.0 \mathrm{~m}$ (e.g., see static groundwater depth map, Yilmaz and Yavuzer 2005).

\section{Earthquake hazard analysis of Yalova region}

Deterministic and probabilistic analyses were used to evaluate the seismic hazard in the region. The potential earthquake source area was considered to be the North Anatolian Fault beneath the Marmara Sea. Historical (32 AD-1900) and measured (1900-2002) seismicities of major earthquakes in the region are shown in figure 2(a); major and minor fault systems, including the northern branch of the Anatolian Fault and the Golcuk, Izmit, and Çinarcik Faults, among others, are shown in figure $2(\mathrm{~b})$.

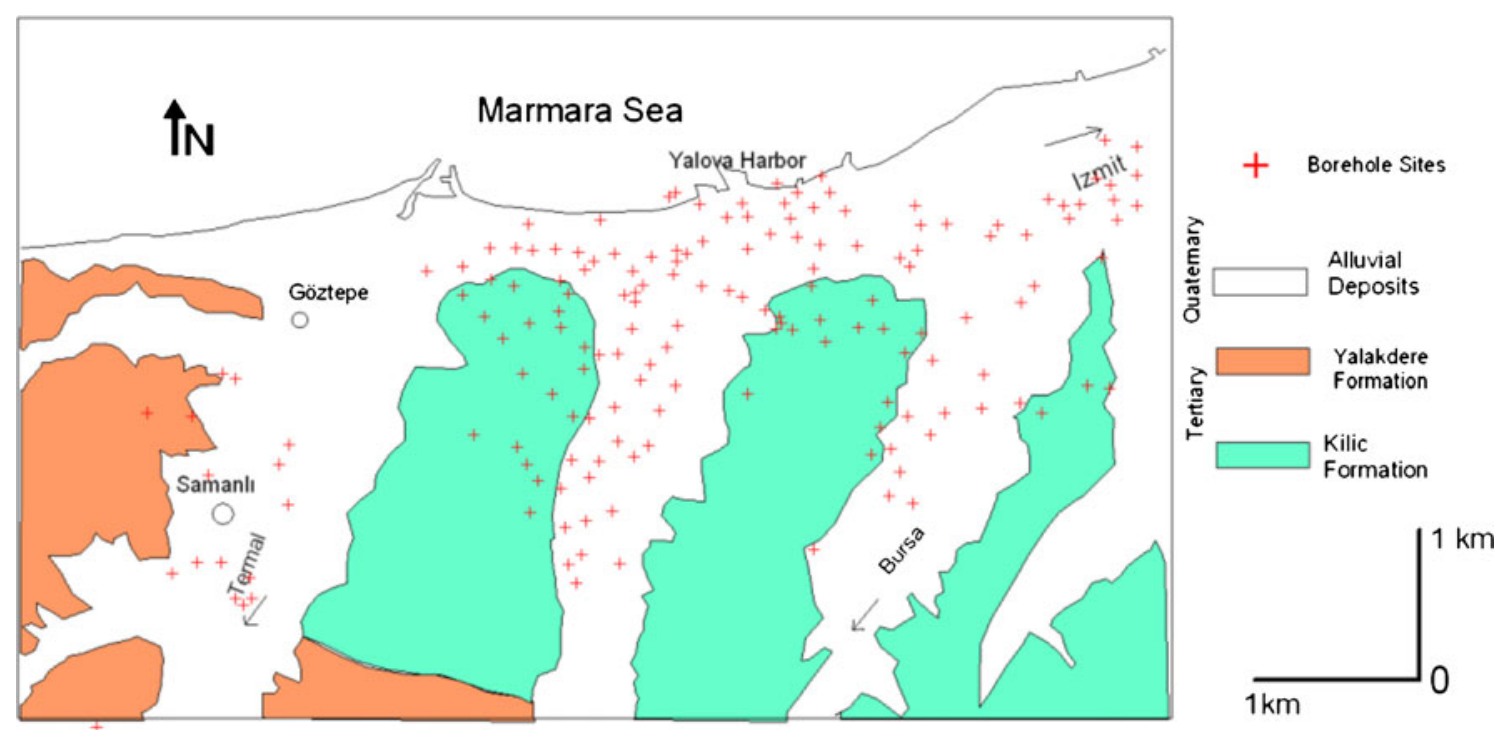

Figure 1. Study area, geology of Yalova region and borehole sites. 

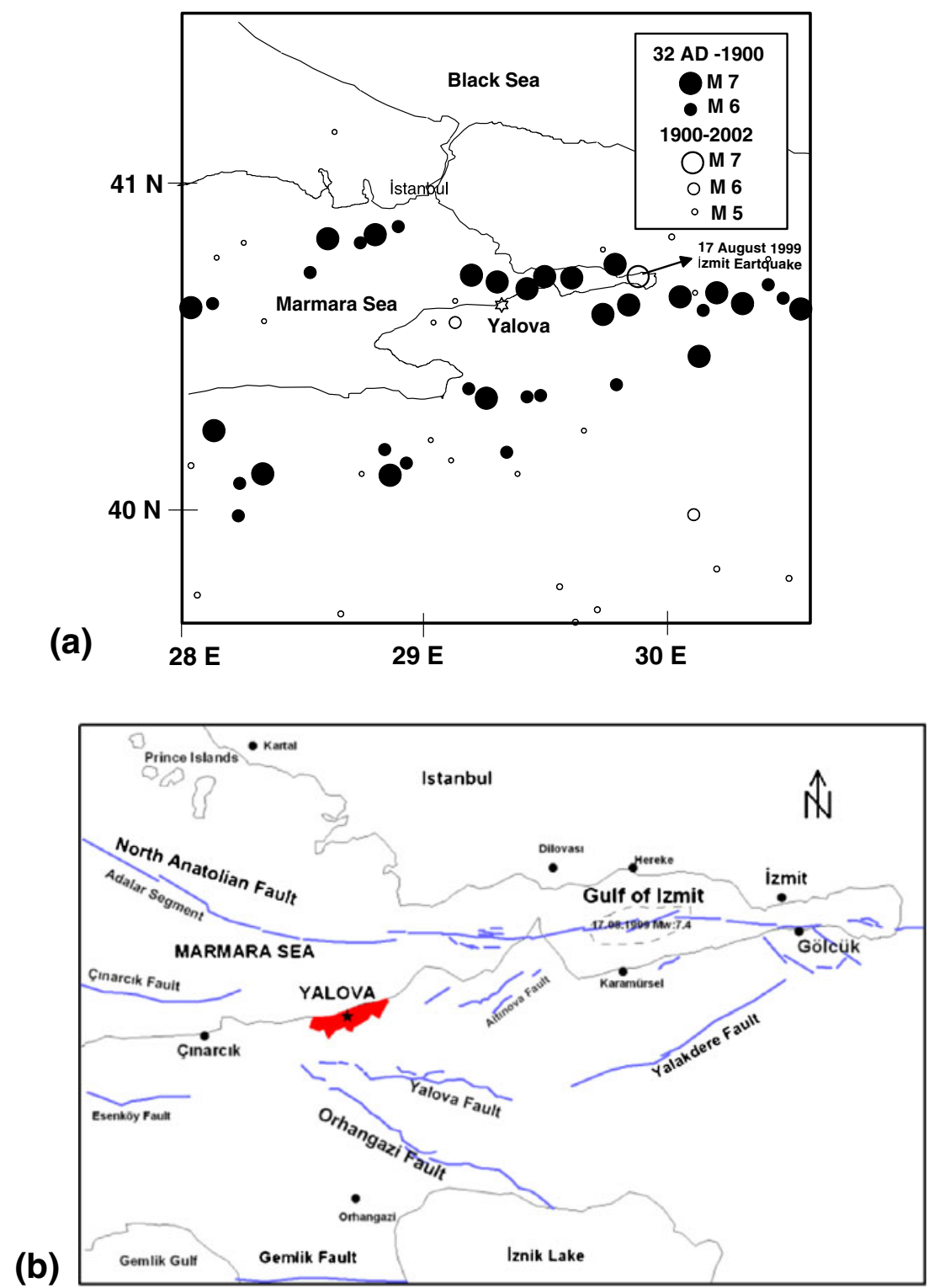

Figure 2. (a) Historical and instrumental seismicity of Yalova City and its vicinity (redrawn from Erdik et al. 2004a). (b) Main and minor fault systems in study area and its vicinity (redrawn from Emre et al. 2011).

\subsection{Deterministic seismic hazard analysis}

Required input for deterministic hazard analysis is a means of designating active faults or earthquake sources in the region. The following models have been proposed for the Marmara region (JICA-IBB, 2002):

Model A: Approximately $119 \mathrm{~km}$ rupture length; Model B: Approximately $108 \mathrm{~km}$ rupture length;

Model C: Approximately $174 \mathrm{~km}$ rupture length (figure 3a).

Table 1 shows these model estimations of expected earthquakes. Also, Erdik et al. (2004a, b) followed the same approach. These models (figure 3a) essentially identify the fault segments for different structural, tectonic and geometrical features and historical earthquake occurrences for the main Marmara Fault. Magnitudes of the hypothetical earthquakes were estimated (table 1).

\subsection{Probabilistic seismic hazard analysis of region}

Table 2 gives the number and magnitude of earthquakes in the study area within a $100 \mathrm{~km}$ radius of Yalova. Earthquake data was obtained from Kalafat et al. (2007), who catalogued seismic activity in Turkey for 105 years since 1900 . Relevant to the present study, about 81 earthquakes of magnitude $M>4.5$ occurred during 


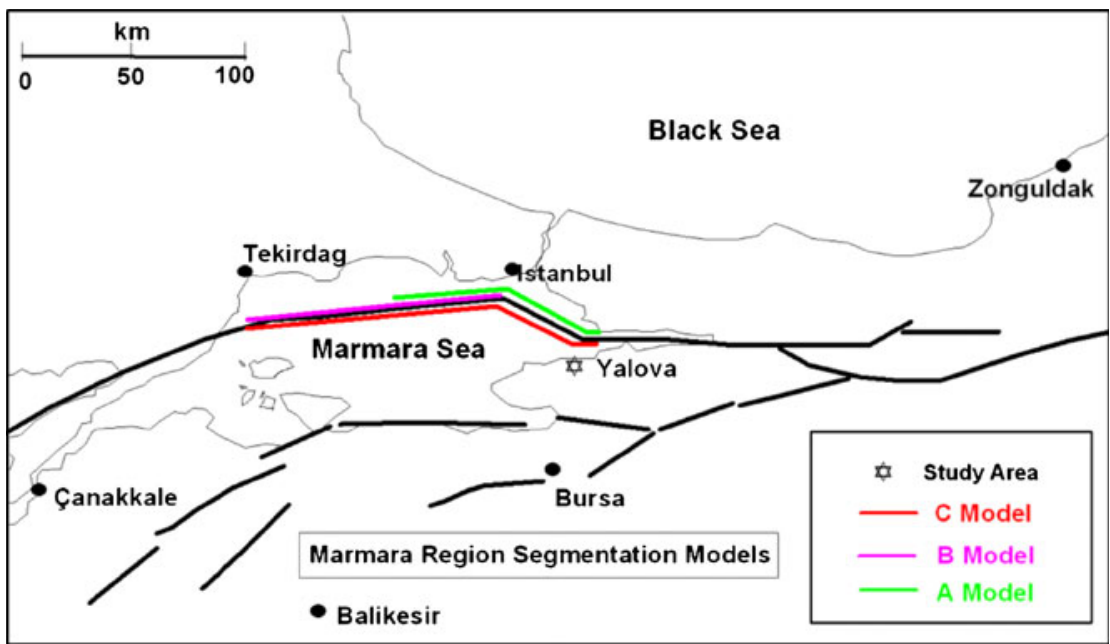

(a)

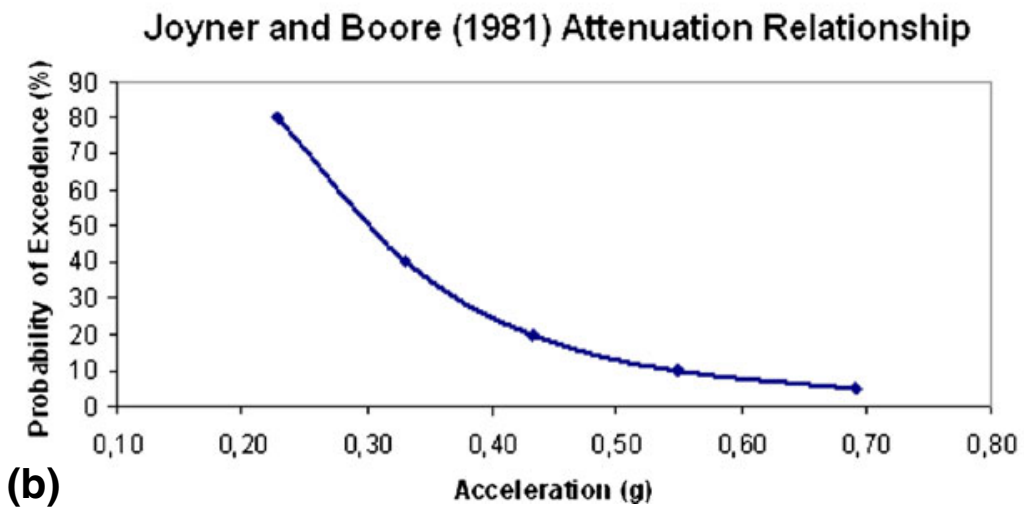

Mw = 7.0 Damping: $5 \%$

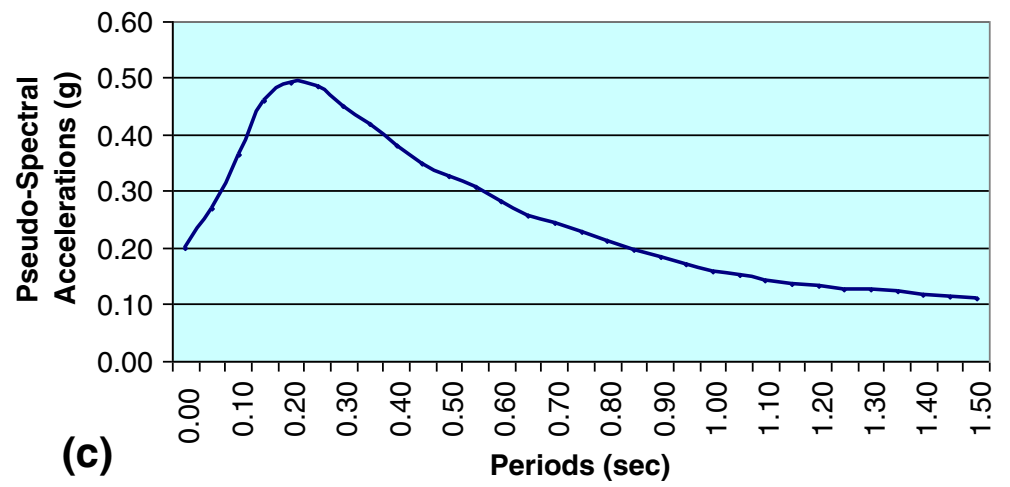

Figure 3. (a) Proposed models A, B, C for deterministic seismic hazard analysis in the Marmara region. A: approximately $119 \mathrm{~km}$ rupture length; B: approximately $108 \mathrm{~km}$ rupture length; C: approximately $174 \mathrm{~km}$ rupture length (redrawn from JICA-IBB, 2002 and Erdik et al. 2004a, b). (b) Hazard curve for region by using Joyner and Boore (1981) attenuation model, and (c) pseudo-spectral acceleration estimations for study area.

this period. The catalogue includes the regions with high seismic activity in Turkey and adjoining areas. One destructive and damaging earthquake $(M s>7.0)$ occurred in the study region during that period of 105 years. The catalogue entries are homogeneous, and all of the earthquake data was modified into a standard format for this study. The $M w$ values were used to estimate the probability of earthquake occurrence in the region.

The Gutenberg-Richter recurrence relationship is determined as:

$$
\log (N)=2.55-0.58 M .
$$


Table 1. Earthquake magnitude estimates for Model A: approximately $120 \mathrm{~km}$ rupture length; Model B: approximately $109 \mathrm{~km}$ rupture length; and Model C: approximately $174 \mathrm{~km}$ rupture length.

\begin{tabular}{lccc}
\hline & \multicolumn{3}{c}{$M$ (magnitude) range for } \\
\cline { 2 - 4 } Researcher & Model A & Model B & Model C \\
\hline Ambraseys and Zatopek (1969) & 7.4 & 7.4 & 7.6 \\
Douglas and Ryall (1975) & 7.5 & 7.5 & 7.7 \\
Patwardhan et al. (1980) & 7.4 & 7.4 & 7.6 \\
Toksöz et al. (1979) & 7.3 & 7.2 & 7.5 \\
Wells and Coppersmith (1994) & 7.5 & 7.4 & 7.7 \\
\hline
\end{tabular}

Table 2. Earthquakes within approximately $100 \mathrm{~km}$ radius of Yalova.

\begin{tabular}{|c|c|c|c|c|c|}
\hline Magnitude $(M w)$ & $4.5 \leq M<5.0$ & $5.0 \leq M<5.5$ & $5.5 \leq M<6.0$ & $6.0 \leq M<6.5$ & $7.0 \leq M<7.5$ \\
\hline Numbers & 54 & 15 & 9 & 2 & 1 \\
\hline
\end{tabular}

Table 3. Probability of earthquake occurrence in the region.

\begin{tabular}{lcccc}
\hline Magnitude & $\begin{array}{c}\text { For } D=10 \text { (years) } \\
\text { Probability (\%) }\end{array}$ & $\begin{array}{c}\text { For } D=50 \text { (years) } \\
\text { Probability (\%) }\end{array}$ & $\begin{array}{c}\text { For } D=75 \text { (years) } \\
\text { Probability }(\%)\end{array}$ & $\begin{array}{c}\text { For } D=100(\text { years }) \\
\text { Probability }(\%)\end{array}$ \\
\hline 5 & 98.5 & 100.0 & 100.0 & 100.0 \\
5.5 & 82.0 & 100.0 & 100.0 & 100.0 \\
6 & 50.4 & 97.0 & 99.5 & 99.9 \\
6.5 & 24.9 & 76.2 & 88.4 & 94.3 \\
7 & 11.1 & 44.4 & 58.5 & 69.0 \\
7.5 & 4.7 & 21.3 & 30.2 & 38.1 \\
\hline
\end{tabular}

The probability of earthquake occurrence is given by:

$$
R m=1-\exp ^{-[N(M) \cdot D]}
$$

where $R m$ is the risk value (\%), and $N(M)$ is the number of earthquakes of magnitude $M$ occurring during time $D$. Table 3 shows the earthquake occurrence probability for the region predicted by equation (2).

Attenuation relationships are defined by two models. From a set of attenuation relationships, the hypothetical acceleration values for the city were calculated as $0.43 \mathrm{~g}$ (from the Joyner and Boore 1981 model) and $0.47 \mathrm{~g}$ (from the Campbell 1997 model) with exceeding probability of $20 \%$ in 50 years. Finally, a hazard curve for the region was estimated (figure $3 \mathrm{~b}$ ).

The ground motion scaling relationships were reviewed for the current study; more recent relationships with much improved datasets were applied for the region of interest using the Akkar and Boomer (2010) approach. Figure 3(c) shows the estimated pseudo-spectral acceleration in the study area for the ground motion relationships $M w=7.0$ and $5 \%$ damping.

\section{Theory for liquefaction analysis and liquefaction induced settlements}

The most widely used simplified SPT- $N$ method is that proposed by Seed et al. (2001) for liquefaction analysis. This method calculates the earthquakeinduced cyclic stress ratio $(C S R)$ in a soil layer from the simplified equation:

$$
C S R=\frac{0.65\left(A_{\max } / g\right)\left(\sigma_{0} / \sigma_{0}^{\prime}\right) \operatorname{rd}(z)}{\operatorname{MSF}(M)},
$$

where $\sigma_{0}^{\prime}$ and $\sigma_{0}$ are the effective and total vertical overburden pressures at some specified depth; $A_{\max }$ is the peak horizontal ground acceleration; $\operatorname{rd}(z)$ is the stress reduction factor at depth $z$; and $\operatorname{MSF}(M)$ is a magnitude scaling factor that considers the duration effect of different earthquake magnitudes. In equation (3), $\sigma_{0}^{\prime}$ and $\sigma_{0}$ are directly computed from borehole logs and laboratory test data, and can therefore be regarded as deterministic values with no variance; $\operatorname{rd}(z)$ and $\operatorname{MSF}(\mathrm{M})$ vary with depth and earthquake magnitude. The factor of safety with respect to liquefaction, FS, can then be calculated from:

$$
F S=\frac{C S R}{C R R}
$$

where $C R R$ is the cyclic resistance ratio. 
The criteria for evaluating the liquefaction resistance based on SPT, CPT or shear-wave data are largely embodied in the CRR vs. N1, 60 plot (Youd et al. 2001). This procedure is based on the relationship of SPT $N$-values, corrected for both effective overburden stress and energy, equipment and procedural factors affecting SPT testing (to N1, 60values) versus intensity of cyclic loading, expressed as magnitude-weighted equivalent uniform cyclic stress ratio $\left(C S R_{\mathrm{eq}}\right)$. The correlation between corrected N1,60-values and the intensity of cycling required to trigger liquefaction is also a function of fines content.

Iwasaki et al. (1982) quantified the severity of possible liquefaction at any site by introducing a factor called the liquefaction potential index, $P L$, defined as:

$$
P L=\int F(z) w(z) \cdot d z,
$$

where $z$ is the depth of the watertable (metres); $F(z)$ is a function of the liquefaction resistance factor, $F S$, where $F(z)=1-F S$ (note that $F(z)=0$ when $F S>1.0)$; and $w(z)=10-0.5 z$. Equation (4) gives values of $P L$ ranging from 0 to 100.

In the last phase of the liquefaction analysis, by using Ishihara and Yoshimine's (1992) approach, total soil settlement, $S$, was estimated from:

$$
S=\sum H \varepsilon,
$$

where $H$ is the thickness of the soil layer, and $\varepsilon$ $(=\Delta H / H)$ is the volumetric strain in the layer, estimated as in Ishihara and Yoshimine (1992).

\section{Theory for site-effect estimations from microtremor and earthquake data}

The site effect is expressed in terms of a transfer function. Its basic principle comprises a simple twolayer model: a hardrock basement is covered by a soft sedimentary layer of thickness $h$ and shearwave velocity $V_{S}$. Resonant frequencies of this system in the small-strain range occur when the layer thickness is an uneven multiple of $\lambda / 4$. The transfer function has maxima at the frequencies given by Ibs-von Seht and Wohlenberg (1999):

$$
f=\frac{n V_{S}}{4 h} \quad \text { for } n=(1,3,5, \ldots) .
$$

Nakamura $(1989,2000)$ proposed a straightforward technique for evaluating local site effects by calculating the spectral ratio between the horizontal components and vertical components of the observed motion at the same site.

\section{Liquefaction analysis and induced settlements for region}

In this study, a practical reliability-based method

\begin{tabular}{|c|c|c|}
\hline Depth & $\operatorname{SPT}(N)$ & Lithology \\
\hline \multicolumn{3}{|l|}{ BH-80 } \\
\hline 1,5 & 7 & $\mathrm{~S}$ \\
\hline 3 & 7 & S \\
\hline 4,5 & 8 & $\mathrm{~S}$ \\
\hline 6 & 9 & S \\
\hline 7,5 & 9 & S \\
\hline 9 & 11 & S \\
\hline 10,5 & 6 & $\mathrm{~S}$ \\
\hline 12 & 10 & $\mathrm{~S}$ \\
\hline \multirow[t]{2}{*}{13,5} & 6 & $\mathrm{MC}$ \\
\hline & GWL & $2,15 \mathrm{~m}$ \\
\hline \multicolumn{3}{|l|}{ BH-83 } \\
\hline 1,5 & 10 & CS \\
\hline 3 & 9 & $\mathrm{~S}$ \\
\hline 4,5 & 9 & S \\
\hline 6 & 10 & $\mathrm{~S}$ \\
\hline 7,5 & 17 & C \\
\hline 9 & 22 & C \\
\hline 10,5 & 26 & C \\
\hline 12 & 27 & C \\
\hline 13,5 & 28 & $\mathrm{C}$ \\
\hline \multirow[t]{2}{*}{15} & 32 & $\mathrm{C}$ \\
\hline & GWL & 2,41 \\
\hline \multicolumn{3}{|l|}{ BH-101 } \\
\hline 1,5 & 6 & $\mathrm{~S}$ \\
\hline 3 & 8 & S \\
\hline 4,5 & 6 & S \\
\hline 6 & 7 & S \\
\hline 7,5 & 8 & S \\
\hline 9 & 7 & $\mathrm{~S}$ \\
\hline 10,5 & 6 & $\mathrm{C}$ \\
\hline 12 & 8 & $\mathrm{C}$ \\
\hline \multirow[t]{2}{*}{13,5} & 12 & $\mathrm{C}$ \\
\hline & GWL & 2,41 \\
\hline \multicolumn{3}{|l|}{ BH-71 } \\
\hline 1,5 & 12 & $\mathrm{~S}$ \\
\hline 3 & 12 & $\mathrm{~S}$ \\
\hline 4,5 & 17 & $\mathrm{~S}$ \\
\hline 6 & 26 & $\mathrm{C}$ \\
\hline 7,5 & 31 & $\mathrm{C}$ \\
\hline 9 & 29 & $\mathrm{C}$ \\
\hline 10,5 & 29 & $\mathrm{C}$ \\
\hline 12 & 40 & $\mathrm{C}$ \\
\hline 13,5 & 39 & $\mathrm{C}$ \\
\hline \multirow[t]{2}{*}{15,3} & 40 & $\mathrm{C}$ \\
\hline & GWL & 2,41 \\
\hline
\end{tabular}
was developed for assessing the soil liquefaction

Table 4. Some borehole logs in the study area.

$\mathrm{GWL}=$ Groundwater level, $\mathrm{S}=$ Sand, $\mathrm{C}=$ Clay, $\mathrm{MC}=$ Silty clay, CS = Clayey sand. 


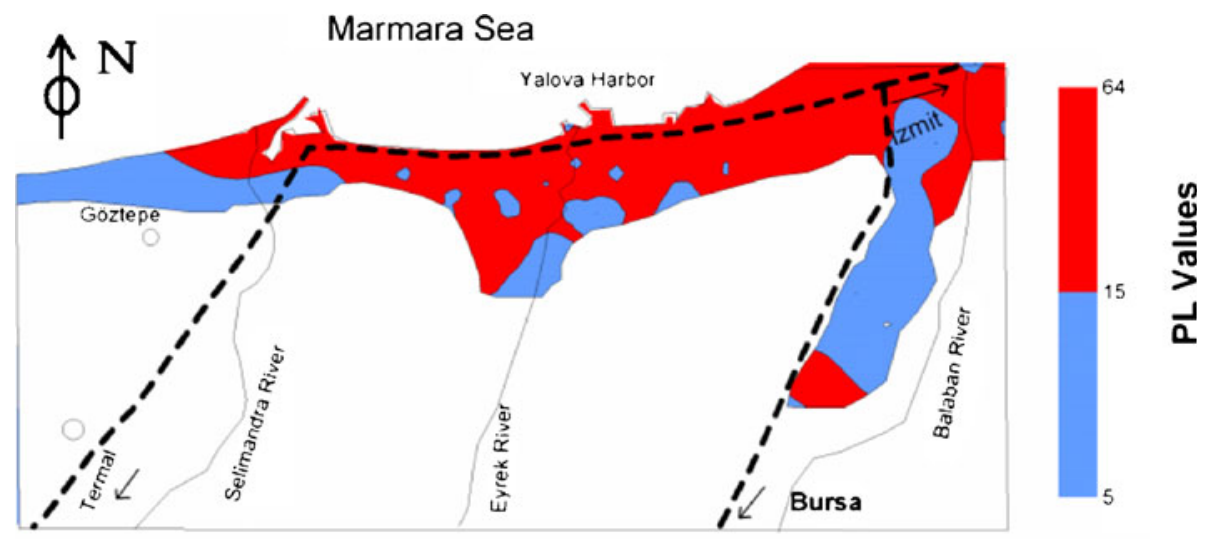

a : $0.40 \mathrm{~g} \mathrm{M}: 7.0$

Figure 4. Variations of $P L$ values for hypothetical earthquake (0.40 g and $M=7.4)$, using Iwasaki et al. (1982) approach.

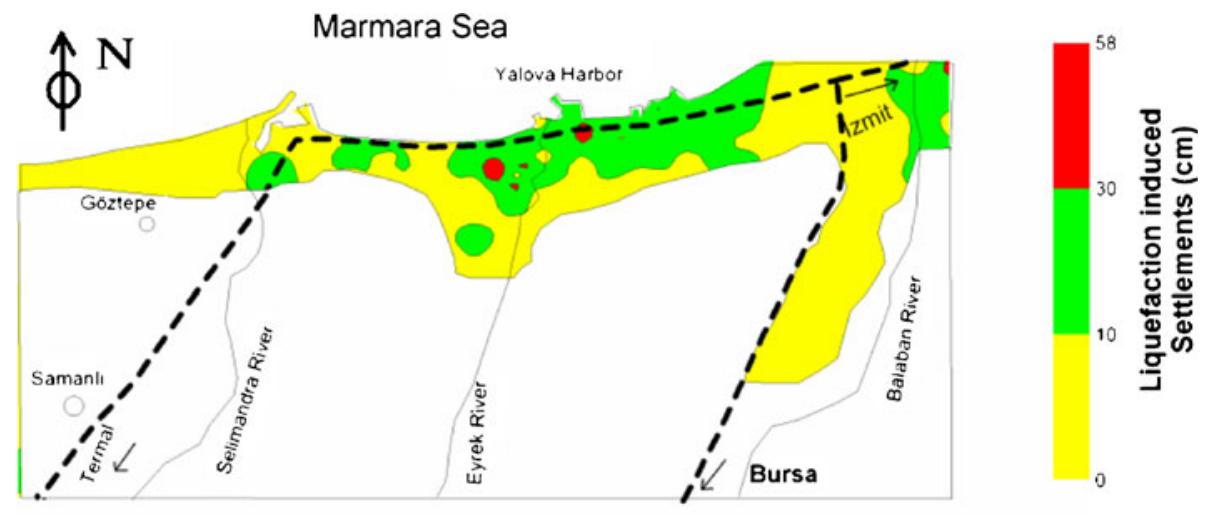

a : $0.40 \mathrm{~g} \quad \mathrm{M}: 7.4$

Figure 5. Variations of settlements for hypothetical earthquake (0.40 g and $M=7.4)$ using Ishihara and Yoshimine (1992) approach.

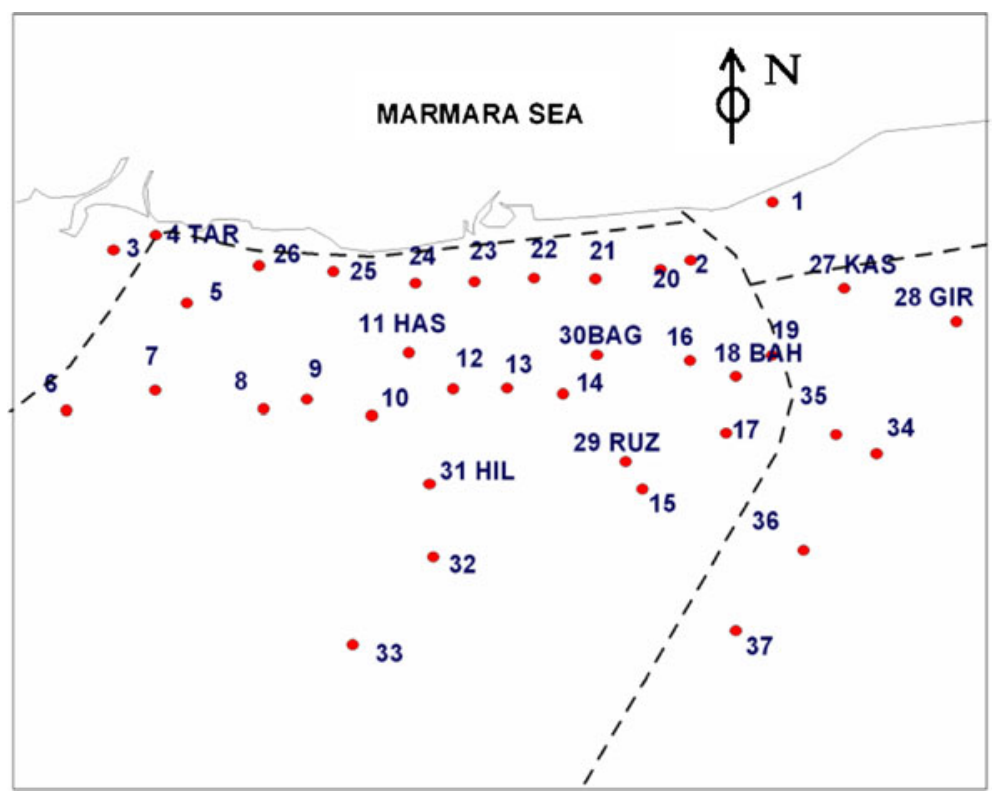

Figure 6. Distribution of microtremor and permanent strong ground motion station in Yalova region. 
potential in the Yalova region. Some typical borehole logs of SPT- $N$, lithology and ground water levels in the study area are illustrated in table 4 . In selecting a scenario earthquake, we used not only deterministic hazard analysis, but also integrated the deterministic and probabilistic seismic hazard analyses to estimate the level of ground motion (i.e., its magnitude and acceleration).

For liquefaction analysis, magnitudes of 6.5, 7.0, 7.4 and 7.5 and accelerations of $0.25,0.40$ and $0.50 \mathrm{~g}$ were selected for the hypothetical earthquake. Variations of $P L$ values (by the Iwasaki et al. 1982 approach) for a hypothetical earthquake $(0.40 \mathrm{~g}$ and $M=7.4)$ are shown in figure 4 , and liquefaction-induced settlements (using the Ishihara and Yoshimine 1992 approach) are shown in figure 5.

\section{Site effects from geophysical (microtremor and earthquake) and geotechnical data for region}

\subsection{Geophysical field experiments}

The first experiment was carried out from 9 October 1999 to 6 March 2000. A network of nine stations was deployed in Yalova (figure 6).

Table 5. The list of recorded local earthquakes (Red: 12 November, 1999 Duzce earthquake (Mw 7.2), Green: evaluated earthquake records, Yellow: $S / N$ is high).

\begin{tabular}{|c|c|c|c|c|c|c|c|c|c|c|}
\hline Event Date & TIME & Mag & BAG & BAH & GIR & KAS & HIL & HAS & RUZ & TAR \\
\hline 09.10 .1999 & $6: 23$ & 3.20 & & & & & & & ruz 01 & \\
\hline 11.10 .1999 & $3: 47$ & 3.90 & bag_001 & & & kas 001 & & has 001 & ruz & \\
\hline 11.10 .1999 & $15: 26$ & 3.40 & bag_002 & & gir26401 & kas_002 & & has 003 & ruz & tar_002 \\
\hline 15.10 .1999 & 18:08 & 2.80 & & & & & & & ruz & \\
\hline 21.10 .1999 & $0: 08$ & 4.40 & & & gir29400 & & & & ruz & \\
\hline 23.10 .1999 & $3: 49$ & 3.10 & & & & & & & ruz 002 & \\
\hline 07.11 .1999 & $16: 54$ & 5.00 & & & & & hil 002 & & & \\
\hline 11.11 .1999 & 14:41 & 5.70 & & bah 009 & & & & & & \\
\hline 11.11 .1999 & $15: 42$ & 3.20 & bag 003 & & & kas 003 & hil_003 & has 004 & & \\
\hline 12.11 .1999 & $16: 57$ & 7.20 & bag 004 & bah 010 & gir31600 & kas 004 & hil 004 & has 005 & ruz & tar 004 \\
\hline 12.11 .1999 & $17: 17$ & 5.20 & & & & & hil 005 & 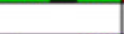 & ruz 041 & tar 005 \\
\hline 12.11 .1999 & $17: 18$ & 5.40 & bag_005 & & & kas_005 & hil_006 & has_ 006 & ruz 043 & \\
\hline 12.11.1999 & $17: 23$ & 5.10 & & & & & & & ruz $\quad 044$ & \\
\hline 12.11.1999 & $17: 47$ & 4.80 & & & & & & & ruz $\quad 045$ & \\
\hline 12.11.1999 & $17: 54$ & 4.70 & & & & & & & ruz $\quad 046$ & \\
\hline 12.11 .1999 & $18: 14$ & 5.00 & & & & & & & ruz 047 & \\
\hline 13.11 .1999 & $0: 54$ & 4.70 & & & & & & & ruz 048 & \\
\hline 13.11 .1999 & $10: 55$ & 3.60 & & & & & & has_007 & ruz 049 & tar_006 \\
\hline 13.11 .1999 & $15: 16$ & 3.30 & & & & & hil_007 & has 008 & ruz 052 & tar_007 \\
\hline 13.11 .1999 & $21: 33$ & 3.30 & & & & & & & ruz_053 & tar_008 \\
\hline 14.11.1999 & $6: 04$ & 3.00 & bag009 & & gir31802 & & hil 010 & & & $\operatorname{tar} \quad 012$ \\
\hline 14.11 .1999 & $5: 17$ & 3.40 & bag 006 & bah 011 & gir31800 & kas 006 & hil 008 & has 009 & ruz 054 & $\operatorname{tar} \quad 009$ \\
\hline 14.11 .1999 & $5: 43$ & 2.80 & bag $\quad 007$ & & & & & & ruz 055 & tar 010 \\
\hline 14.11 .1999 & $5: 55$ & 3.50 & bag 008 & bah 012 & gir31801 & kas 007 & hil 009 & has 010 & ruz 056 & tar 011 \\
\hline 15.11 .1999 & 5:05 & 3.20 & & & gir31900 & & & & ruz 058 & \\
\hline 17.11 .1999 & $8: 15$ & 5.00 & & & & & & & ruz 064 & \\
\hline 17.11 .1999 & $14: 51$ & 3.00 & & & & & & & ruz 066 & \\
\hline 18.11 .1999 & $21: 49$ & 3.30 & & & & & & & ruz 069 & tar_013 \\
\hline 19.11 .1999 & $19: 59$ & 5.00 & & & & & & & ruz $\quad 075$ & \\
\hline 20.11 .1999 & $20: 42$ & 3.00 & & & & & & & ruz_ 077 & tar__014 \\
\hline 21.11 .1999 & $2: 15$ & 2.60 & & & & & & & ruz 078 & \\
\hline 22.11 .1999 & $4: 36$ & 3.10 & bag_ 010 & & & & hil_018 & & ruz_ 081 & tar \\
\hline 23.11 .1999 & $20: 38$ & 3.40 & bag_ 012 & & & & hil_020 & has_ 011 & ruz_ 092 & tar_017 \\
\hline 25.11 .1999 & $16: 13$ & 3.20 & & & & & & & ruz_099 & tar_018 \\
\hline 25.11 .1999 & $17: 54$ & 3.20 & & & & & & & ruz 100 & tar 019 \\
\hline 25.11 .1999 & 19:16 & 3.10 & & & & & & & & tar 020 \\
\hline 27.11 .1999 & $2: 42$ & 3.30 & bag 013 & bah 013 & & kas 008 & hil 022 & has 012 & ruz 107 & $\operatorname{tar} 021$ \\
\hline 07.12 .1999 & $14: 46$ & 3.60 & bag 014 & bah 014 & & kas 009 & hil 024 & has 014 & & $\operatorname{tar} \quad 022$ \\
\hline 09.12 .1999 & 11:38 & 3.80 & bag 015 & & & kas 010 & hil 025 & has 015 & & tar_023 \\
\hline 10.12 .1999 & $2: 03$ & 3.60 & bag_016 & & & & hil_026 & & & tar_024 \\
\hline 16.12 .1999 & $1: 38$ & 3.50 & bag017 & bah015 & & kas_011 & hil027 & & & \\
\hline 16.12.1999 & $1: 44$ & 3.20 & & & & kas__012 & & & & \\
\hline 16.12 .1999 & $12: 32$ & 3.50 & bag018 & & & kas 013 & hil028 & has016 & & \\
\hline 11.01 .2000 & $14: 38$ & 3.40 & bag019 & & & & & & & \\
\hline 15.01 .2000 & $10: 32$ & 3.10 & & & & & & & & $\operatorname{tar} 017$ \\
\hline 17.01 .2000 & $10: 34$ & 3.20 & & & & kas_ 014 & hil030 & has018 & & \\
\hline 31.01 .2000 & $14: 38$ & 4.10 & bag020 & & & kas_ 015 & hil031 & has019 & & $\operatorname{tar} 025$ \\
\hline 31.01 .2000 & $14: 44$ & 3.50 & & & & kas__016 & hil032 & has020 & & \\
\hline 06.03 .2000 & $15: 44$ & 3.30 & & & & & hil033 & & & \\
\hline
\end{tabular}



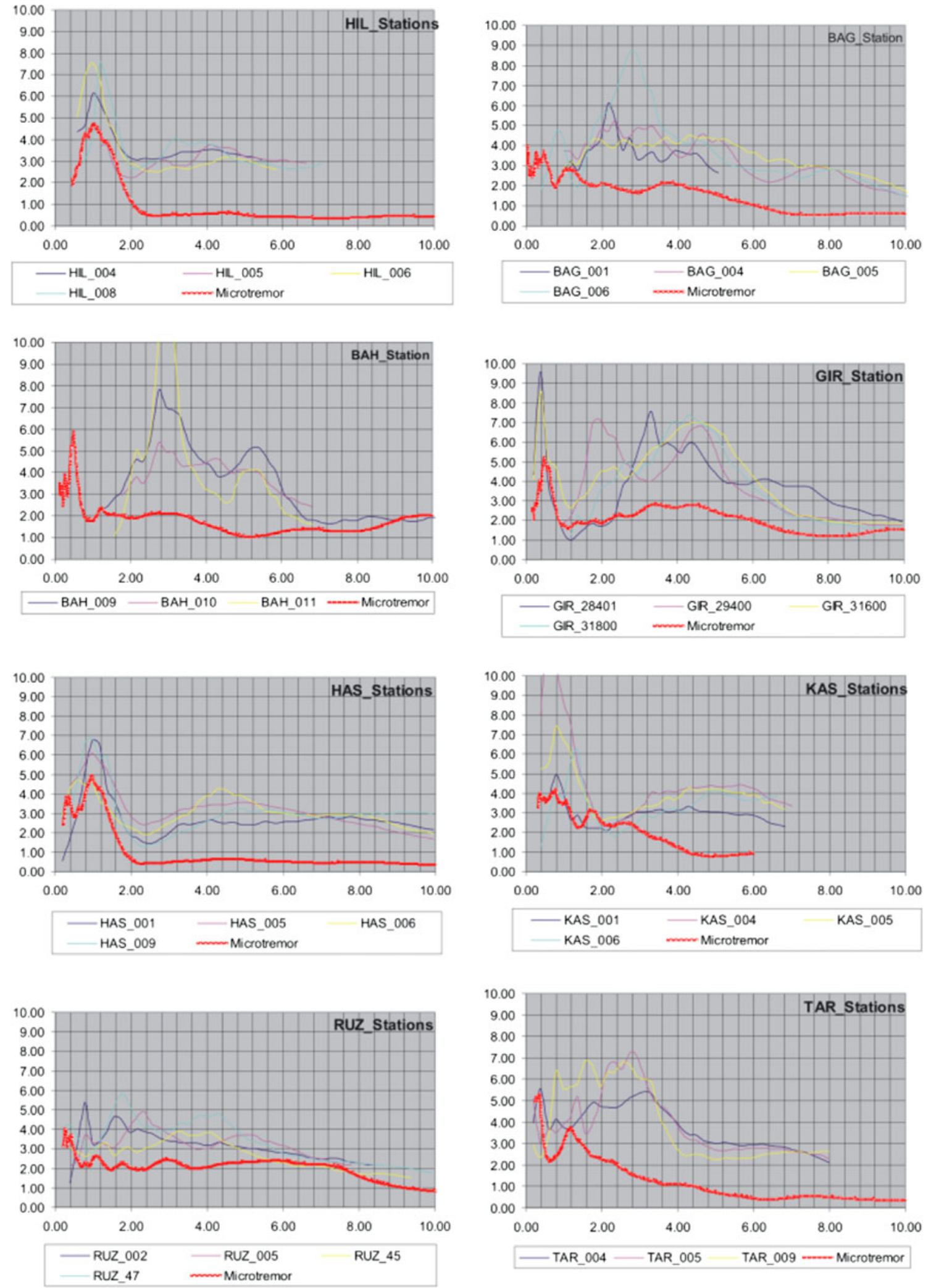

Figure 7. Comparison of $H / V$ ratios obtained from microtremor and earthquake records. Red: $H / V$ spectral ratio of microtremor. Other colours are $H / V$ ratio of earthquake data. Scale $\mathrm{X}$ : $0-10, \mathrm{Y}$ : 0-10. 
Table 6. Recorded ambient noise.

\begin{tabular}{|c|c|c|c|c|}
\hline $\begin{array}{l}\text { Microtremor } \\
\text { station code }\end{array}$ & Latitude & Longitude & $\begin{array}{l}\text { Altitude } \\
\quad(\mathrm{m})\end{array}$ & $\begin{array}{c}\text { Range of } \\
\text { measurement time }\end{array}$ \\
\hline 1 & 403939.6 & 291701.8 & 1 & $13: 25-13: 40$ \\
\hline 2 & 403931.9 & 291649.0 & & $14: 10-14: 30$ \\
\hline 3 & 403925.0 & 291442.3 & 7 & $14: 50-15: 10$ \\
\hline 4- TAR & 403928.6 & 291454.9 & 5 & $15: 20-15: 35$ \\
\hline 5 & 403917.1 & 291459.2 & & $15: 55-16: 15$ \\
\hline 6 & 403858.9 & 291434.1 & 7 & $16: 30-16: 45$ \\
\hline 7 & 403902.6 & 291453.5 & 44 & $17: 00-17: 15$ \\
\hline 8 & 403900.3 & 291516.9 & 34 & $17: 30-17: 45$ \\
\hline 9 & 403902.4 & 291525.6 & 23 & $18: 15-18: 40$ \\
\hline 10 & 403900.2 & 291539.7 & 7 & $18: 55-19: 20$ \\
\hline 11-HAS & 403910.6 & $\begin{array}{lll}29 & 15 & 47.0\end{array}$ & 6 & $19: 35-19: 55$ \\
\hline 12 & 403905.5 & 291556.8 & 12 & $20: 15-20: 35$ \\
\hline 13 & 403905.5 & 291608.1 & & $20: 50-21: 05$ \\
\hline 14 & 403905.5 & 291620.0 & 21 & $21: 25-21: 45$ \\
\hline 15 & 403850.7 & 291637.7 & 97 & $22: 05-22: 25$ \\
\hline 16 & 403911.5 & 291647.6 & 17 & $22: 45-23: 00$ \\
\hline 17 & 403900.4 & 291655.2 & 50 & $23: 10-23: 30$ \\
\hline 18-ВАН & 403907.0 & 291655.2 & 14 & $00: 50-01: 05$ \\
\hline 19 & 403913.3 & 291703.8 & 6 & 01:15-01:30 \\
\hline 20 & 403926.3 & 291640.2 & 2 & $01: 47-02: 05$ \\
\hline 21 & 403924.4 & 291626.5 & 10 & $02: 20-02: 40$ \\
\hline 22 & 403923.8 & 291612.9 & 4 & 02:50-03:10 \\
\hline 23 & 403922.4 & 291600.5 & 1 & $03: 20-03: 40$ \\
\hline 24 & 403922.2 & 291548.0 & 14 & $03: 50-04: 10$ \\
\hline 25 & 403923.3 & 291529.7 & 1 & $04: 15-04: 35$ \\
\hline 26 & 403923.4 & 291513.8 & 3 & 04:40-05:00 \\
\hline 27-KAS & 403924.8 & $\begin{array}{llll}29 & 17 & 17.5\end{array}$ & 7 & $05: 20-05: 35$ \\
\hline 28-GIR & 403920.2 & $\begin{array}{lll}29 & 17 & 43.9\end{array}$ & 5 & $07: 40-08: 00$ \\
\hline 29-RUZ & 403854.7 & 291635.4 & 48 & $08: 20-08: 40$ \\
\hline 30-BAG & 403910.3 & 291626.3 & 7 & $09: 05-09: 25$ \\
\hline 31-HIL & $4038 \quad 49.7$ & $2915 \quad 52.1$ & 1 & $09: 45-10: 00$ \\
\hline 32 & 403837.8 & 291554.4 & 12 & $12: 10-12: 30$ \\
\hline 33 & 403823.2 & 291538.5 & 5 & $12: 45-13: 00$ \\
\hline 34 & 403858.4 & 291727.6 & 9 & $13: 35-13: 50$ \\
\hline 35 & 403900.9 & 291719.3 & 3 & $14: 05-14: 15$ \\
\hline 36 & 403842.4 & 291713.0 & 2 & $14: 25-14: 40$ \\
\hline 37 & 403828.6 & 291659.3 & 18 & $14: 50-15: 05$ \\
\hline
\end{tabular}

(Bold: place of strong ground motion station).

SSA-12 recording stations equipped with Kinemetrics sensors were installed at eight sites inside buildings. Data was recorded at a sampling rate of $200 \mathrm{~Hz}$. The stations were synchronised to a GPS reference time. Subsequently, 49 local earthquakes were recorded. The station information and magnitudes of the recorded earthquakes are shown in table 4.

The second experiment was carried out from 10 pm (local time) on 11 April 2009 to 12 pm (local time) on 12 April 2009 with the aim of recording ambient noise. Data was recorded at 37 sites using Guralp CMG-6TD sensors (standard flat velocity
Table 7. Soil Model A estimation of soil amplification.

\begin{tabular}{lll}
\hline Model A & $z=15 \mathrm{~m}$ & $V_{S}, 15$ \\
\hline$z=15+, V_{S}$ is unknown & \\
$V_{S} 30=\left(V_{S}, 15+V_{S}\right.$, last layer $) / 2$ & \\
\hline
\end{tabular}

response between 0.033 and $50 \mathrm{~Hz}$ ) located were shown in figure 6 . The recorded ambient noise measurements are listed in table 5. At each site the signal was recorded with a sampling rate of $100 \mathrm{~Hz}$ for at least $15 \mathrm{~min}$. The stations were synchronised to a GPS reference time. 


\subsection{Comparisons between ambient noise and earthquake data}

For comparison of ambient noise and earthquake data, $H / V$ spectral ratios were used to calculate all of the data. Since the earthquakes on 17 August and 12 November 1999, Yalova City has been affected by many major earthquakes, two of which caused more than 1000 deaths. USGS and KOERI (Department of Earthquake Engineering) installed a local array of eight accelerographs in the centre of the city (station codes: TAR, HIL, BAG, BAH, RUZ, HAS, KAS and GIR). All of the stations were installed on soft soil at the locations shown in figure 6. This local array recorded 49 earthquakes of magnitudes ranging from 3.0 to 7.2 , as well as some shallow events. If the fundamental resonance of the soil overlaps the natural frequencies of buildings, damage can be increased. (Figure 7 shows the comparison of $H / V$ ratios obtained from microtremor and earthquake records.) In particular, results from the HIL, GIR, HAS and KAS stations were in agreement with microtremor ratios.
Station HIL is near station 31. Comparison of the $H / V$ ratios of these stations shows fundamental resonance frequency agreement near $1 \mathrm{~Hz}$, but amplification in the earthquake record is greater than that of the microtremor: for example, amplification of microtremor is 4 and for earthquake is 7 .

Station BAG is near station 30. Comparisons of the $H / V$ ratios show fundamental resonance frequency agreement near $1 \mathrm{~Hz}$. When the $H / V$ spectral ratio from four earthquakes was calculated, different amplification values are evident. While BAG_004 and BAG_005 had strong ground motion, BAG_001 and BAG_006 had weak motion; strong ground motion amplification was less than for weak ground motion. While the microtremor spectral ratio showed reduced amplification near the $3 \mathrm{~Hz}$ frequency, the earthquake amplitude data was amplified.

For the BAH earthquake station, the fundamental period was approximately 2.75 and $5.2 \mathrm{~Hz}$ for the earthquake spectra, but the ratio of the microtremor measurement was 0.5 and $2.75 \mathrm{~Hz}$

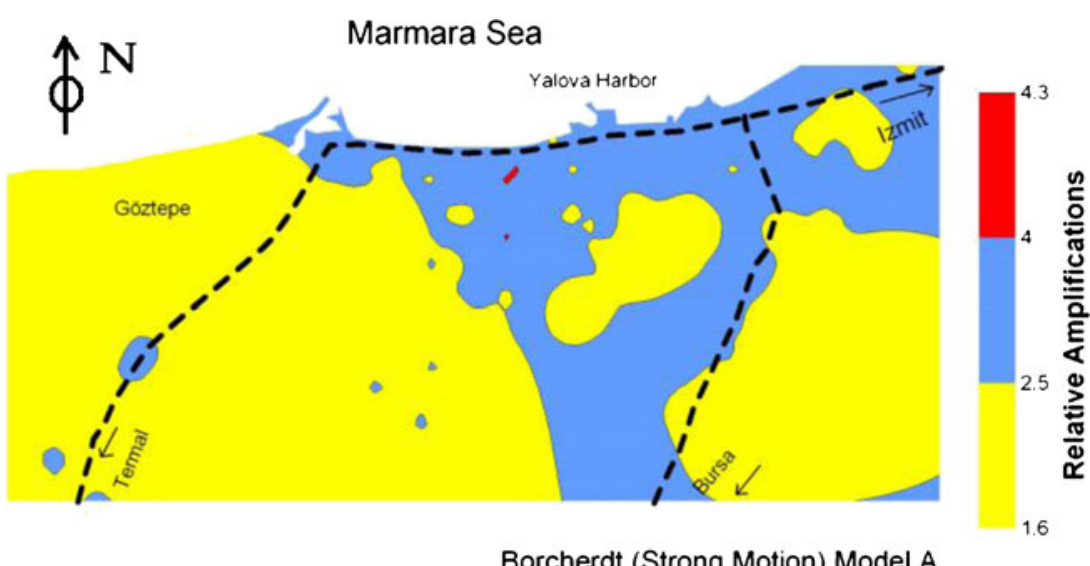

Figure 8. Soil amplification map for the region according to Borcherdt et al.'s (1991) Model A for strong motion.

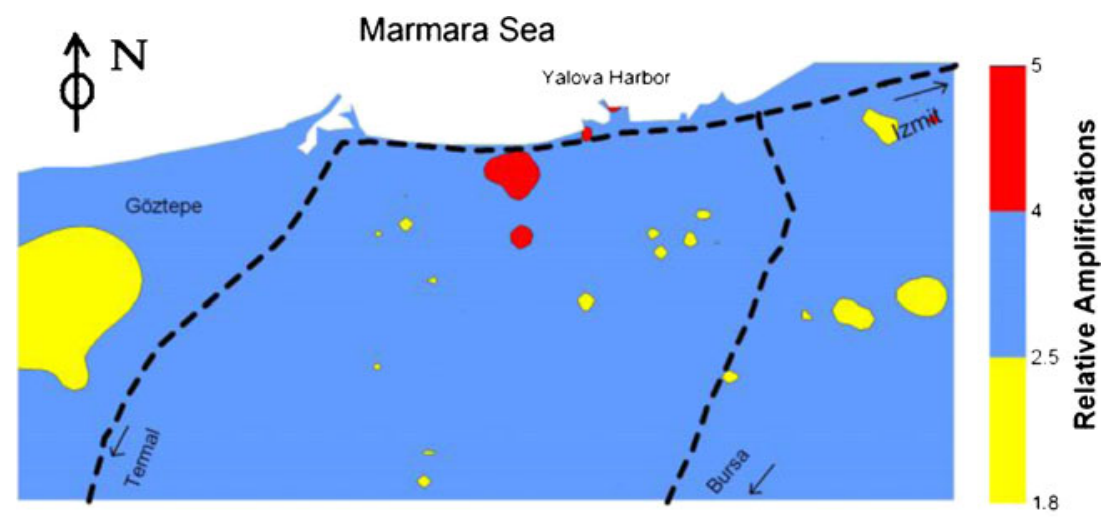

Borcherdt (Weak Motion) Model A

Figure 9. Soil amplification map for the region according to Borcherdt et al.'s (1991) Model A for weak motion. 
at the same point. The amplitude was also larger for earthquakes than for microtremors. Concurrent values of amplitude signal in the microtremor record were reduced to around $5.2 \mathrm{~Hz}$, while the earthquake record was amplified.

Station GIR is near station 28. Comparing the $H / V$ ratios at these stations, two different fundamental frequencies were in evidence, but all were stable at 0.5 for frequencies lower than $1 \mathrm{~Hz}$, but at frequencies above $1 \mathrm{~Hz}$ the ratios were 2.0 and 4.2 for earthquakes and within the broad range of 2.0-6.0 for microtremors. Amplification in the earthquake record was also greater than for the microtremor. Below $1 \mathrm{~Hz}$, the amplification for microtremors was 5, and for earthquakes it was 8; above $1 \mathrm{~Hz}$, it was 2 for microtremors and 7 for earthquakes. Damage distribution showed that the range of these frequencies might overlap the natural frequencies of both the soil and structures in the vicinity of station GIR.

Station HAS is near station 11. Compared to the $H / V$ ratios at these stations, the fundamental resonance frequencies were in agreement around $1 \mathrm{~Hz}$, but the amplification of the earthquake record was greater than for the microtremors ( 7 for earthquakes and 5 for microtremors). There was a second fundamental frequency peak around $4 \mathrm{~Hz}$ evident in the earthquake data.

Station KAS is near station 27. The $H / V$ spectral ratio at station 27 exhibited a broad range of peaks between 0.3 and $1 \mathrm{~Hz}$, and at $0.1 \mathrm{~Hz}$. On comparison of $H / V$ ratios at these stations, fundamental resonance frequencies were seen to be in agreement near $0.7 \mathrm{~Hz}$, but amplification in the earthquake record was greater than that for the microtremor ( 8 for earthquakes and 4 for microtremors). The general shape of the spectrum was the same for both.

Station RUZ is near station 29. The shapes of the spectrum were the same, but the amplifications differed.

Station TAR is near station 4. The shape of the spectrum was different at the two stations. The $H / V$ spectral ratio of the microtremors showed

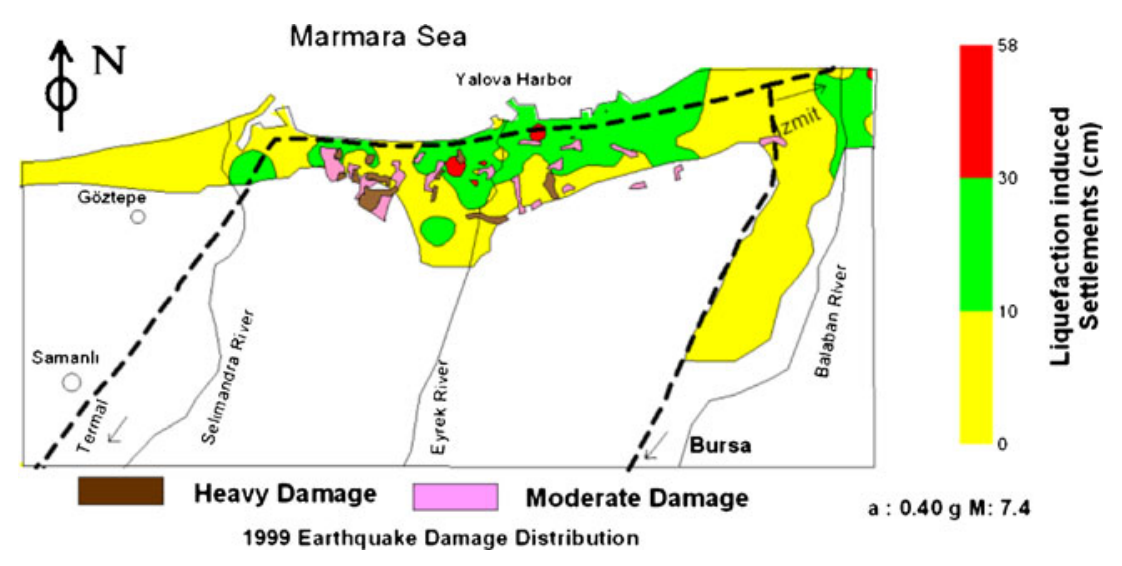

Figure 10. Comparison between damage due to the 17 August 1999 earthquake and liquefaction-induced settlements for a similar earthquake $(0.40 \mathrm{~g}$ and $M=7.4)$.

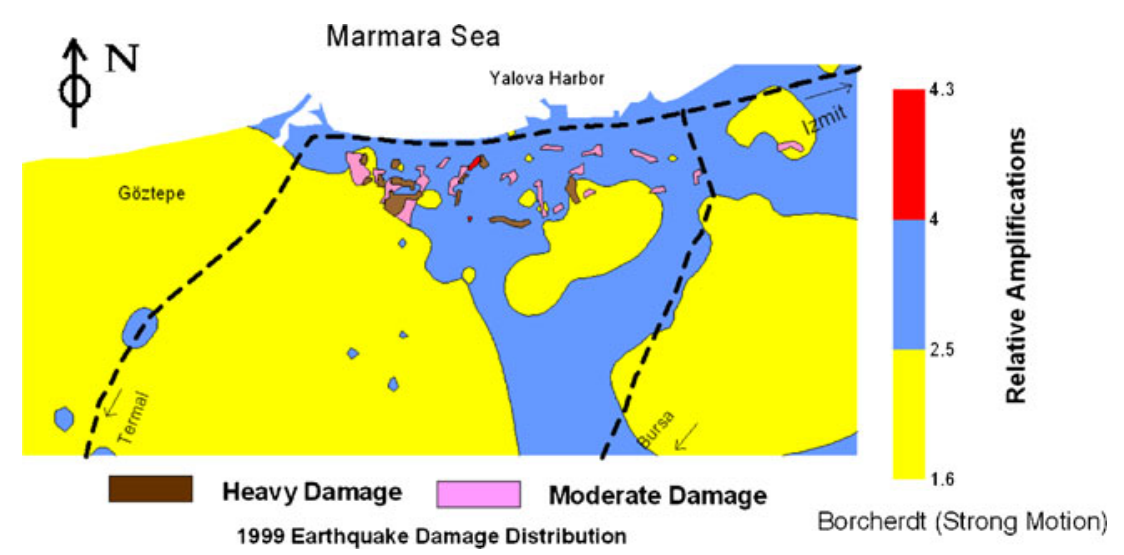

Figure 11. Comparisons between damage from 17 August 1999 earthquake and soil amplifications for the region, using Borcherdt et al.'s (1991) Model A for strong motion. 
two fundamental resonance frequencies, at 0.3 and $1.2 \mathrm{~Hz}$; the shape of the $H / V$ spectrum of the earthquake data showed four separate peaks, at $0.3,1.2,1.56$ and $2.54 \mathrm{~Hz}$.

Observations of the dependence of elastic-wave velocities on stress in soil reveal that significant nonlinear elastic effects may occur during seismic wave propagation. The site materials, whether soil or rocks, are nonlinear materials with a dynamic behaviour strongly dependent on loading level. This affects the whole dynamic response, including the system natural period values (Bratosin et al. 2009). In the present study, the resonance frequencies obtained from the microtremors at many sites were lower than those from actual earthquakes. This may imply that the strain level during microtremors was greater, and the soil modulus was therefore less, than during actual earthquakes. Because a microtremor is an extremely weak ground motion, it cannot produce such a large strain. The deformation characteristics of soils are highly variable and depend on the magnitude of the shear strain in the soil.

According to the scientific literature, ambient seismic noise is thought to be composed of 'microseisms' and 'microtremors'. Whereas microseisms represent long-period noise mainly generated by natural causes, microtremors are short-period noise events with artificial origins. The cutoff point between microtremors and microseisms should not be fixed at a single marginal frequency, for example, at $1 \mathrm{~Hz}$. Microtremor records in our study (as seen in figure 7) are inconsistent at frequencies less than $1 \mathrm{~Hz}$.

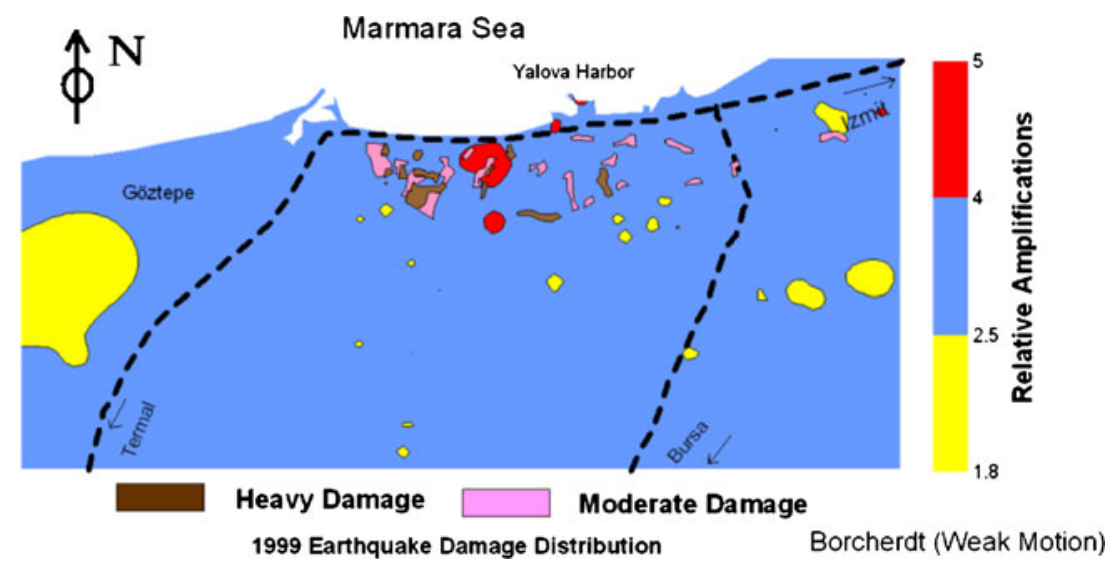

Figure 12. Comparisons between damage from 17 August 1999 earthquake and soil amplifications for the region, using Borcherdt et al.'s (1991) Model A for weak motion.
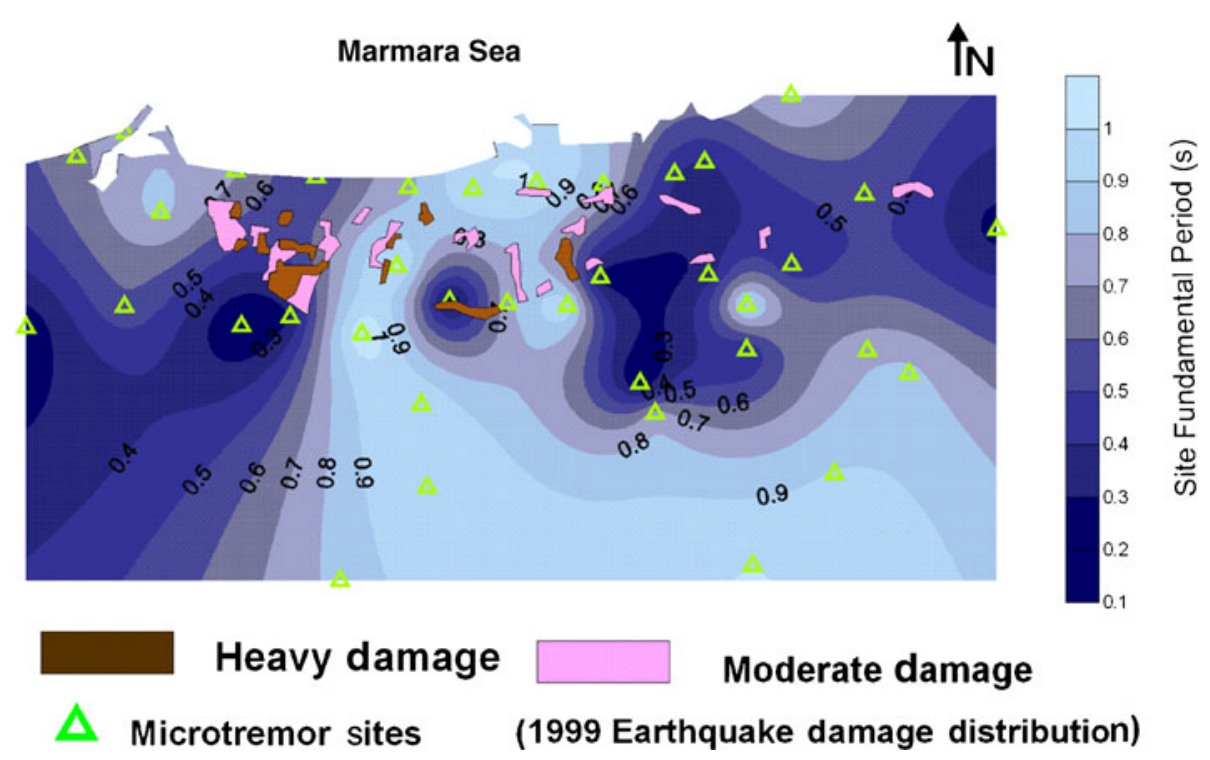

Figure 13. Comparisons between damage of 17 August 1999 earthquake and site fundamental period data, obtained from microtremor measurements. 


\subsection{Soil amplifications obtained from geotechnical data}

In this study, geotechnical data from more than 200 boreholes was evaluated. $\operatorname{SPT}(N)$ values were converted into the equivalent shear-wave velocity values using the relationship given by Iyisan (1996):

$$
V_{S}=51.5(\mathrm{SPT})^{0.516}
$$

It is known that $V_{S}$ is an index property for evaluating soil amplifications. The shear-wave and soil amplification relations from Borcherdt et al. (1991) were obtained. Since the borehole data was for depths of only $15 \mathrm{~m}$, we used their soil Model A to estimate soil amplifications (shown in tables 6 and 7).
Figures 8 and 9 show soil amplification maps for the region according to the Borcherdt et al. (1991) approach for weak and strong motion for Model A.

\section{$7.4 V_{S} 30$ map of soil from geophysical $(M A S W)$ data}

The MASW method deal with surface waves at lower frequencies (e.g., 1-30 Hz) and allows a much shallower depth range of investigation than is otherwise possible (e.g., a few to a few tens of metres) (Park et al. 2007). The shear-wave velocities and profile were obtained by MASW in the study area. The phase velocity-dispersion curve and shearwave velocity were obtained by inversion distance profile for the upper $30 \mathrm{~m}$ of the soil at 100 sites.

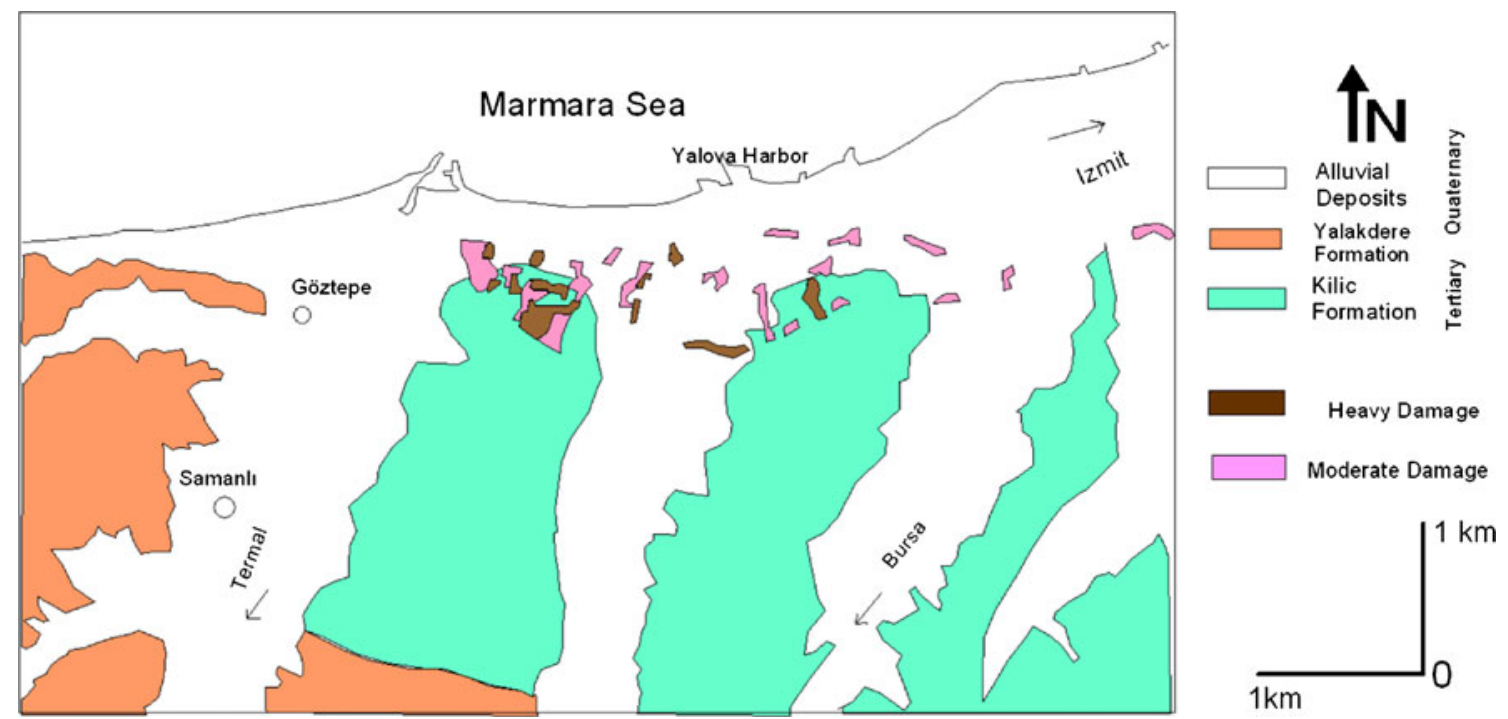

Figure 14. Comparisons between damage of 17 August 1999 earthquake and soil geology.

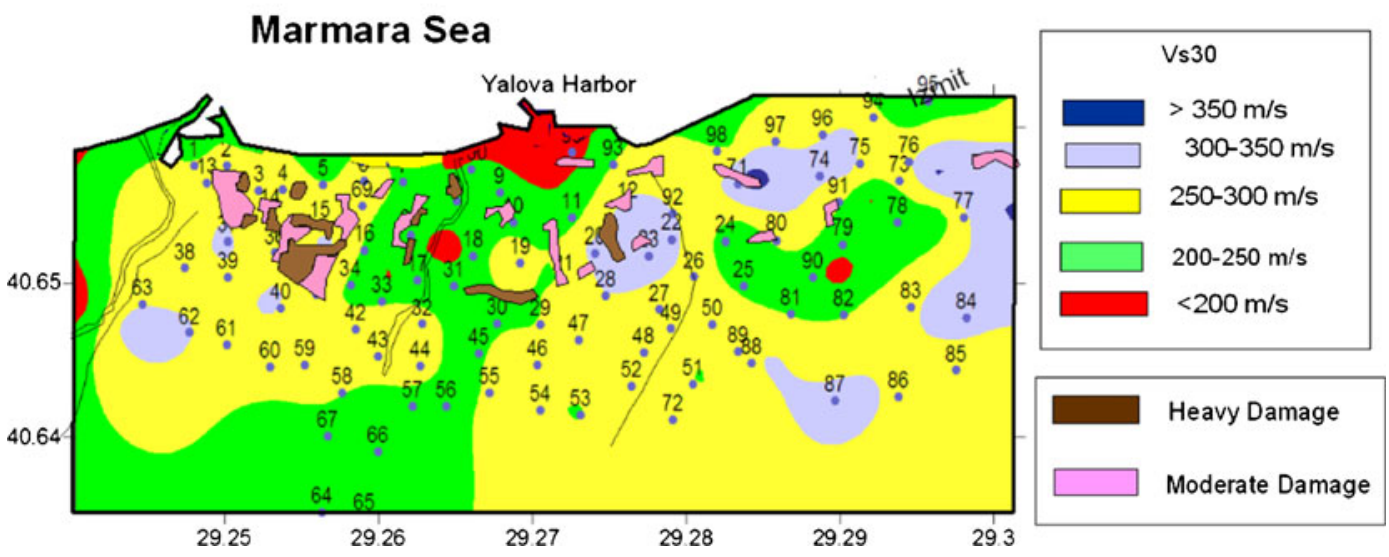

Figure 15. Comparisons between damage of 17 August 1999 earthquake and $V_{S} 30$. 


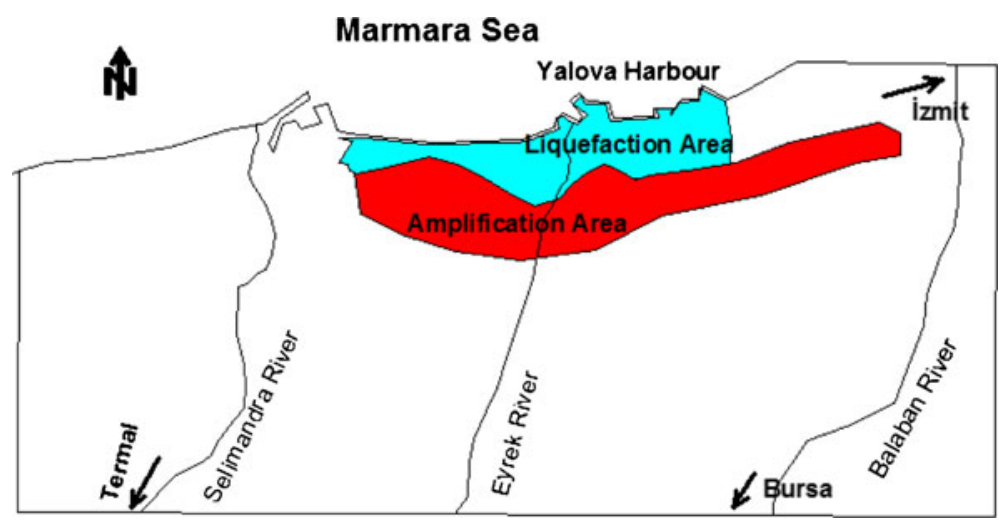

Figure 16. Regions of soil liquefaction and amplification (and/or resonance) produced according to relationships between the damage and geotechnical/geophysical results.

\section{Earthquake damage, liquefaction and site effects}

Comparisons between earthquake damage and liquefaction-induced settlements are given in figure 10 .

Comparisons between 1999 earthquake damage and soil amplifications obtained from geotechnical data are given in figures 11 and 12 for the region according to the Borcherdt et al. (1991) Model A for both strong and weak motion.

Figure 13 compares the damage caused by the 17 August 1999 earthquake and fundamental period data from microtremor site measurements. Figure 14 shows comparisons between the earthquake damage and soil geology. Figure 15 compares the earthquake damage and $V_{\mathrm{S}} 30$.

Finally, the map in figure 16 of the regions affected by soil liquefaction and amplification (and/or resonance) shows the relationships between earthquake damage and the geotechnical and geophysical data.

\section{Conclusions}

Detailed liquefaction-induced ground settlement from geotechnical data, and local site effects from geophysical data, were estimated for Yalova City in order to relate them to the damage to civil engineering structures, triggered by the 1999 earthquake.

The damage patterns from the 17 August 1999 Izmit earthquake were analysed. A wide range of factors affected the damage patterns. Building damage in Yalova was predominantly related to the earthquake-induced behaviour of the soils in the affected areas. Based on the results of our analysis, the following conclusions were drawn:

- For saturated soil conditions, the geological and geomorphological features were considered together with the liquefaction index, $P L$, and induced settlements (figure 4 for $P L$ index, and figure 5 for liquefaction-induced settlement). It was concluded that some Quaternary deposits in the study area sustained mainly light-tomoderate damage levels, with a minor proportion of extensive damage (the criteria are set out in Ishihara and Yoshimine 1992) occurring with increasing values of earthquake variables.

- The strong ground motion data and ambient noise measurement recordings carried out in Yalova allowed us to compare microtremors and earthquakes. Comparisons of the $H / V$ ratio from the microtremor and earthquake results illustrated that there is generally a good agreement in the shape of the $H / V$ curve, especially where the fundamental peak occurs at frequencies above $1 \mathrm{~Hz}$. This agreement was not observed for the whole signal shape, however. For periods $<1 \mathrm{~s}$, due to the nonlinear effect of earthquake motion in these types of weak soils, no strong relationship was seen between microtremor and earthquake data. Moreover, despite their variability, the $H / V$ results may provide the lower bound level of amplification with respect to earthquake data. Significant amplifications (i.e., exceeding 5) were observed at all of the stations located on very thick sediments. This indicates that those higher frequencies, which may overlap the resonance frequencies of buildings, might not necessarily be damped out under such conditions. Therefore, the fundamental resonance frequency from the $H / V$ ratio should be adopted as the lower-bound frequency for site amplifications. Figure 13 is a map of fundamental period and damage distribution for sites in Yalova after the 17 August 1999 earthquake. In particular, while heavy damage focused (figure 13) on the period range $0.5-0.7 \mathrm{~s}(1.42-2 \mathrm{~Hz})$, moderate damage was sustained for $0.8-1 \mathrm{~s}$ periods $(1-1.25$ $\mathrm{Hz})$. The fundamental frequency of $H / V$ ratios 
for both microtremor and strong ground motion (figure 7) are not in agreement below $0.625 \mathrm{~s}$ $(1.6 \mathrm{~Hz})$.

- Figures 5 and 10 indicate that critical soil settlement occurred in the alluvial deposits. This area focuses on the coastal areas of the study area. Any damage to this area can be associated with liquefaction (especially settlements between 10 and $30 \mathrm{~cm}$ ). As we know from soil mechanic studies, settlements up to $10 \mathrm{~cm}$ can be neglected in terms of structural damage. There was also significant damage in the region outside the liquefiable area. Geologically, the area is in the Tertiary Kılıç formation (figure 14). The $V_{S} 30$ values in this area (figure 15) exceeded $250 \mathrm{~m} / \mathrm{s}$. This value is insufficient to cause liquefaction, but it is significant for soil amplification; therefore, it may be inferred that soil amplification was responsible for damage in this region. Comparisons between damage and soil amplification for strong motion (figure 11) for this area show that soil amplification values varied between 2.5 and 4.0 , and the period values (figure 13), seem to have a threshold value of $0.7 \mathrm{~s}$. Sites with period values $>0.7 \mathrm{~s}$ may be related to soil liquefaction-induced damage, and sites where the period $<0.7 \mathrm{~s}$ incurred damage solely due to soil amplification and/or resonance.

- Soil amplification has a linear effect on soil behaviour, but soil liquefaction has a nonlinear effect. In Yalova sites, the soil amplification effect may predominate at nonsandy soil sites. There is a striking liquefaction effect in sandy soils. In the vicinity of fields, soil behaviour becomes increasingly complex. For this reason, no distinction could be drawn between the two types of soil behaviour in Yalova City. Relating to the damage, the critical boundary between site amplification and soil liquefaction is determined by shear-wave velocity, $V_{S}$, and site resonance period: if $V_{S}<250 \mathrm{~m} / \mathrm{s}$, soil liquefaction is dominant; if resonance period $<0.7 \mathrm{~s}$, soil amplification and/or resonance may be dominant.

- The work of Borcherdt et al. (1991) on amplifications for low strain or strong motion data and corresponding regressions as a function of shear-wave velocity is a theoretical approach to estimating the average horizontal spectral amplifications in the period range 0.4$2.0 \mathrm{~s}$. Theoretical considerations are also valid for settlement estimation; in most cases, earthquake damage is related to three types of factor-soil behaviour, earthquake motion and building quality. Each factor contains within it some degree of uncertainty, and this is the reason for the weak agreement between actual events and calculated amplifications and settlements.

\section{Acknowledgements}

This work was mainly supported by the Research Fund of the Istanbul University (Projects: BYP:12823 and YADOP-6708, YADOP-23171). Some part of this study was also supported by the Research Fund of the Istanbul University of Istanbul (Project: UDP:29989 and UDP:22428). Furthermore, earthquake data used in this study was taken from temporally strong motion stations installed by the Bogazici University Kandilli Observatory and Earthquake Research Institute. The authors wish to thank Bogazici University Kandilli Observatory. Lastly, authors would like to thank Barış Karabulut and Louise Karabulut at the University of Glamorgan (UK) for editing the manuscript.

\section{References}

Akkar S and Boomer J J 2010 Empirical equations for the prediction of PGA, PGV, and spectral accelerations in Europe, the Mediterranean Region, and the Middle East; Seismol. Res. Lett. 81 195-206.

Ambraseys N and Zatopek A 1969 The Mudurnu valley earthquake of July 22nd 1967; Bull. Seismol. Soc. Am. 59 21-89.

Borcherdt R D and Gibbs J F 1976 Effects of local geological conditions in the San Francisco Bay Region on ground motions and the intensities of the 1906 earthquake; Bull. Seismol. Soc. Am. 66 467-500.

Borcherdt R D, Wentworth C M, Glassmoyer G, Fumal T, Mork P and Gibbs J 1991 On the observation, characterization, and predictive GIS mapping of ground response in the San Francisco Bay region, California; Proc. 4 th Int. Conf. Seismic Zonation, Stanford, CA 3 545-552.

Bratosin D, Balan F and Cioflan C 2009 Soils nonlinearity effects on dominant site period evaluation; Proc. Romanian Acad., Series A 10.

Campbell K W 1997 Empirical near-source attenuation relationships for horizontal and vertical components of peak ground acceleration, peak ground velocity, and pseudoabsolute acceleration response spectra; Seismol. Res. Lett. 8 154-179.

Chou H S, Yang C Y, Hsieh B J and Chang S S 2001 A study of liquefaction related damages on shield tunnels; Tunn. Undergr. Sp. Tech. 16 185-193.

Douglas M B and Ryall A 1975 Return periods for rock acceleration in western Nevada; Bull. Seismol. Soc. Am. 65 1599-1611.

Emre Ö, Doğan A, Duman T and Özalp Y 2011 1:250,00 Scale Active Fault Map Series of Turkey, Bursa (NK 3512) Quadrangle, Serial Number 9; General Directorate of Mineral Research and Exploration, Ankara, Turkey.

Erdik M, Demircioğlu M, Sesetyan K, Durukal E and Siyahi B 2004a Earthquake hazard in Marmara Region, Turkey; Soil Dyn. Earthq. Eng. 24 605-631.

Erdik M, Demircioğlu M, Sesetyan K, Durukal E and Siyahi B 2004b Earthquake hazard in Marmara Region, Turkey; Proc. 13th World Conf. Earthq. Eng., Vancouver, Canada, August 1-6, Paper 270.

Gueguen P, Chatelain J, Guillier B, Yepes B and Egred, J 1998 Site effect and damage distribution in Pujili 
(Ecuador) after the 28 March 1996 earthquake; Soil Dyn. Earthq. Eng. 17 329-334.

Ibs-von Seht M and Wohlenberg J 1999 Microtremor measurements used to map thickness of soft soil sediments; Bull. Seismol. Soc. Am. 89 250-259.

Iglesias J 1988 Seismic microregionalization of Mexico City after the 1985 earthquake; Proc. 9th World Conf. Earthq. Eng. 2 127-132.

Ishihara K and Yoshimine M 1992 Evaluation of settlements in sand deposits following liquefaction during earthquakes; Soils Found. 32 173-188.

Iwasaki T, Tokida K, Tatsuoka F, Watanabe S, Yasuda S and Sato H 1982 Microzonation for soil liquefaction potential using simplified methods; Proc. 3rd Int. Conf. Microzonation, Seattle, pp. 1319-1330.

Iyisan R 1996 Correlations between shear-wave velocity and in-situ penetration test results; Teknik Dergi 7 1187-1199 (in Turkish).

JICA-IBB 2002 Study of a Disaster Prevention/Mitigation Basic Plan in Istanbul including Seismic Microzonation in the Republic of Turkey, Final Report. Main Report, December 2002; Pacific Consultants International, OYO Corporation, Japan International Cooperation Agency (JICA), Istanbul Metropolitan Municipality (IMM), $729 \mathrm{p}$.

Joyner W B and Boore D M 1981 Peak acceleration and velocity from strong motion records including records from the 1979 Imperial Valley, California, earthquake; Bull. Seismol. Soc. Am. 71 2011-2038.

Juang C H, Yuan H, Li D K, Yang S H and Christopher R A 2005 Estimating severity of liquefaction-induced damage near foundation; Soil Dyn. Earthq. Eng. 25 403411.

Kalafat D, Gunes Y, Kara M, Deniz P, Kekovali K, Kuleli S, Gulen L, Yllmazer M and Ozel N M 2007 A Revised and Extended Earthquake Catalog for Turkey Since 1900 $(M>4.0)$; Bogazici University Kandilli Observatory and Earthquake Research Institute, Istanbul.

Lekkas E L 1996 Pyrgos earthquake damages (based on E.M.S.-1992) in relation with geological and geotechnical conditions; Soil Dyn. Earthq. Eng. 15 61-68.

Lermo J and Chavez-Garcia F J 1994 Site effect evaluation at Mexico City: Dominant period and relative amplification from strong motion and microtremor records; Soil Dyn. Earthq. Eng. 13 413-423.
Nakamura Y 1989 A method for dynamic characteristics estimations of subsurface using microtremors on the ground surface; Quart. Rep. Railw. Tech. Res. Inst. 30 25-33.

Nakamura Y 2000 Clear identification of fundamental idea of Nakamura's technique and its application; Proc. 12th World Conf. Earthq. Eng., Auckland, New Zealand 8.

Ozcep F and Zarif H 2009 Variations of soil liquefaction safety factors depending on several design earthquakes in the City of Yalova (Turkey); Sci. Res. Essays 4 594-604.

Özel O, Cranswick E, Meremonte M, Erdik M and Safak, E 2002 Site effects in Avcilar, west of Istanbul, Turkey, from strong- and weak-motion data; Bull. Seismol. Soc. Am. 92 499-508.

Park C B, Miller R D, Xia J and Ivanov J 2007 Multichannel analysis of surface waves (MASW) - active and passive methods; The Leading Edge, January 2007, pp. 60-64.

Patwardhan A S, Kulkarni R B and Tocher D 1980 A semi-Markov model for characterizing recurrence of great earthquakes; Bull. Seismol. Soc. Am. 70 323-347.

Seed H B, Cetin K O and Moss R E S 2001 Recent advances in soil liquefaction engineering and seismic site response evaluation; Proc. 4th Int. Conf. Recent Advances in Geotech. Earthq. Eng. and Soil Dynamics, and Symp. in Honor of Prof. W D Liam Finn San Diego, California, March 26-31.

Toksöz M N, Shakal A F and Michael A J 1979 Spacetime migration of earthquakes along the North Anatolian Fault Zone and seismic gaps; Pure Appl. Geophys. 117 1258-1270.

Wells D L and Coppersmith K J 1994 New emprical relationships among magnitude, rupture length, rupture width, rupture area, and surface displacement; Bull. Seismol. Soc. Am. 84 974-1002.

Yilmaz I and Yavuzer D 2005 Liquefaction potentials and susceptibility mapping in the city of Yalova, Turkey; Environ. Geol. 47 175-184.

Youd T L, Idriss I M, Andrus R D, Arango I, Castro G, Christian J T, Dobry R, Finn W D L, Harder L F Jr, Hynes M E, Ishihara K, Koester J P, Liao S S C, Marcuson W F, Martin R, Mitchell J K, Moriwaki Y, Power M S, Robertson P K, Seed R B and Stokoe K H 2001 Liquefaction resistance of soils: Summary Report from the 1996 NCEER and 1998 NCEER/NSF Workshops on Evaluation of Liquefacton Resistance of Soils; J. Geotech. Eng. 127 817-833. 